Володимир Семенович Кивлюк (кандидат економічних наук, доцент)

Віктор Іванович Лазоренко (кандидат військових наук, доцент)

Юрій Олександрович Ганненко

Михайло Петрович Лаврук

Національний університет оборони України імені Івана Черняховського, Київ, Україна

\title{
ПРОБЛЕМИ УПРАВЛІННЯ СИСТЕМОЮ ЗАБЕЗПЕЧЕННЯ ВІЙСЬКОВИМ МАЙНОМ ВІЙСЬК (СИЛ) ЗБРОЙНИХ СИЛ УКРАЇНИ ТА ШЛЯХИ ЇХ ВИРІШЕННЯ
}

У статті на основі проведеного аналізу забезпечення військ (сил) Збройних Сил України на сучасному етапі розвитку визначені основні проблеми логістики як органу управління системою забезпечення військовим майном військ (сил) Збройних Сил Украӥни та пропонуються шляхи їх вирішення.

Розглядаються питання використання єдиних термінів та понять щзодо забезпечення сил оборони в мирний час та особливий період. Автори визначають одну з головних проблем - це створення ефективної системи забезпечення сил оборони Украӥни, яка спроможна здійснювати планування та управління процесами забезпечення військ (сил) військовим майном як у мирний час, так $і$ в особливий період та буде сумісною із системою НАТО.

Єдине ефективне функиіонування системи забезпечення військовим майном військ (сил) Збройних Сил України становить актуальне завдання для органів військового управління, які організовують забезпечення Збройних Сил України.

Створення системи забезпечення військовим майном військ (сил) Збройних Сил Украӥни, як системи управління матеріальними потоками висуває завдання щзодо об'єднання в єдину систему існуючих видів тилового та технічного забезпечення, наближаючи їх до стандартів НАТО.

Система забезпечення розглядається, як методологія розробки раціональних методів управління забезпеченням військовим майном військ (сил) Збройних Сил Украӥни, направлених на оптимізацію, 3 мінімальними затратами трудових і матеріальних ресурсів.

Наприкінці сформульовані напрямки подальших досліджень щэодо удосконалення системи забезпечення сил оборони України.

Ключові слова: військове майно, інформаційна система, логістика, логістична система, матеріальні засоби.

\section{Вступ}

В умовах коли Україна здійснює оборонну реформу 3 метою набуття та підтримання необхідного рівня оборонних спроможностей, ефективного реагування на загрози та виклики національній безпеці, особлива увага повинна приділятися удосконаленню управління системами забезпечення військ (сил) та іï сумісності 3 державами членів НАТО та СС.

Очікуваним результатом оборонної реформи $є$ створення майбутніх сил оборони. Для досягнення мети оборонної реформи необхідно досягнути ряд цілей та виконати ряд завдань, які визначенні у доктринальних документах розвитку сил оборони України. Одним 3 таких завдань $є$ створення системи управління забезпеченням військовим майном військ (сил), яка відповідає стандартам, доктринам і рекомендаціям НАТО.

Постановка проблеми. Існуючий стан системи забезпечення військ (сил) Збройних Сил України військовим майном та послугами вимагає проведення невідкладних заходів щодо іiі вдосконалення та приведення у відповідність до сучасних вимог. Відсутність науковометодологічної основи ii вдосконалення на сучасному етапі розвитку 3С України призводить до суперечності в задоволенні їх потреб наявними силами і засобами у існуючих умовах.

Під час реформування Збройних Сил України не визначена чітка вертикаль управління видами забезпечення, розподілу повноважень та відповідальності між органами військового управління усіх рівнів.

Створена організаційно-штатна структура, що функціонує в даний час не відповідає сучасним вимогам щодо повного задоволення потреб воєнної організації держави в особливий період (воєнний час).

Забезпечувальні структури, які існують у Міністерстві оборони і Генеральному штабі 3С 
України розбалансовані за підлеглістю і не трансформуються в єдину логістичну систему забезпечення військовим майном збройних формувань держави в особливий період (воєнний час).

Зазначені недоліки стримують практичне впровадження сучасних методів, моделей, методик планування та управління системою забезпечення військовим майном військ (сил), не сприяють підвищенню іiі ефективності.

Аналіз останніх досліджень і публікацій. В останні роки з'явилось дуже багато матеріалів в інтернеті та керівних документах (доктринальних) розвитку сил оборони [1-9] щодо запровадження логістики в Збройних Силах України.

Так, вагомий внесок у розвиток впровадження та застосування логістичного підходу внесли керівні документи [1,2]. У них обгрунтована необхідність створення та використання для підвищення ефективності забезпечення військ (сил) військовим майном логістичної системи.

У наукових статтях [10,11] автори зробили спробу та запропонували удосконалення системи тилового, технічного та медичного забезпечення Збройних Сил України із створення єдиної ефективної системи логістики Збройних Сил України, як системи управління матеріальними, інформаційними і людськими потоками на основі їх оптимізації.

Метою статті $\epsilon$ визначення основних проблем застосування логістики як органу управління системою забезпечення військовим майном військ (сил) України та запропонувати шляхи їх вирішення.

\section{Виклад основного матеріалу дослідження}

Перш ніж розглядати шляхи удосконалення управління системою забезпечення військ (сил) Збройних Сил України військовим майном та послугами необхідно визначитись щодо тлумачення деяких термінів, а саме в таких поняттях, як “логістична система”, “військове майно”, "матеріальні засоби”, “матеріальнотехнічні засоби".

Логістична система - це організаційногосподарський механізм управління матеріальними та інформаційними потоками. Вона включає матеріальні засоби, що забезпечують рух товарів по логістичному ланцюгу (склади, вантажно-розвантажувальні механізми, транспортні засоби), виробничі запаси та засоби управління усіма ланками ланцюга $[12,13]$.

Відповідно керівних документів Збройних Сил України $[1,2]$, логістична система - це сукупність взаємозв'язаних, узгоджених за завданнями органів управління, сил і засобів забезпечення матеріальними засобами та послугами (тилу), транспортних комунікацій та визначений порядок виконання заходів з забезпечення військ (сил).

В законах України, постановах Кабінету Міністрів України та інших керівних (доктринальних) документах і настановах [1-7], при плануванні та забезпечення військ (сил) ці всі поняття застосовуються. Проведений аналіз показує, що у законодавчій базі та керівних документах Збройних Сил України до цього часу немає прийнятого єдиного терміну, який повинен застосовуватись. Так, при розгляді логістичної системи в забезпеченні військ (сил) Збройних Сил України військовим майном та послугами необхідно використовувати єдиний термін, це "військове майно".

Військове майно - це державне майно, закріплене за військовими частинами, закладами, установами та організаціями Збройних Сил України. До військового майна належать будинки, споруди, передавальні пристрої, всі види озброєння, бойова та інша техніка, боєприпаси, пально-мастильні матеріали, продовольство, технічне, аеродромне, шкіперське, речове, культурно-просвітницьке, медичне, ветеринарне, побутове, хімічне, інженерне майно, майно зв'язку тощо. Міністерство оборони України здійснює управління військовим майном, у тому числі закріплює військове майно за військовими частинами (у разі їх формування, переформування), приймає рішення щодо перерозподілу цього майна між військовими частинами, в тому числі у разі їх розформування. Військове майно закріплюється за військовими частинами Збройних Сил України на праві оперативного управління [2,8,9].

Аналіз сутності поняття військове майно показує, що необхідно розрізняти нерухоме військове майно у вигляді будинків, споруд та різних об'єктів розміщених на землі, а також рухоме військове майно, яке здатне переміщуватися (перевозитись). Так, рухоме військове майно - це матеріальні засоби (боєприпаси, пально-мастильні матеріали, продовольство, технічне, аеродромне, шкіперське, речове, культурно-просвітницьке, медичне, ветеринарне, побутове, хімічне, інженерне майно, майно зв'язку тощо) які підвозяться (подаються) військам (силам). При забезпеченні військ (сил) військовим майном необхідно враховувати те, що істотно змінилися види, способи і форми військових дій. При цьому основними способами розгрому противника в операціях (бойових діях) стали: в умовах застосування тільки звичайної зброї - послідовна вогняна поразка і знищення основних угруповань військ першого, другого ешелонів i резервів противника 3 рішучим наступом своїх військ і оволодінням територією агресора до встановлених рубежів. Набагато збільшилися розмах і динамічність операцій (бойових дій).

Революційні перетворення в корінних питаннях військової справи привели до значних змін умов забезпечення військ (сил) військовим майном та послугами в операціях (бойових діях). Перш за все, відбулося багатократне збільшення обсягу завдань щодо забезпечення військ (сил) 
військовим майном. Так, для проведення сучасної оборонної операції оперативного угруповання військ необхідно боєприпасів в 6-8 разів, а пального в 8-10 раз більше, ніж це було в подібних операціях періоду другої світової війни. Розширилися потреби також в ракетноартилерійському, інженерному, хімічному та іншому військовому майні.

У зв'язку з подальшим розвитком озброєння та військової техніки (ОВТ), появою високоточної зброї (ВТЗ), зброї на нових фізичних принципах, а також зміною способів підготовки і ведення операцій (бойових дій), умови забезпечення військ (сил) військовим майном та послугами різко ускладнюються та збільшується їх обсяг. Все це вимагає збільшення складу і можливостей сил i засобів забезпечення військовим майном та послугами i дослідження найбільш ефективних способів їх використання. Проте, не дивлячись на кількісні і якісні зміни, що відбулися, принципові положення щодо забезпечення військ (сил) військовим майном та послугами залишаються в силі і в сучасних умовах. У своїй основі вони є частиною загальних принципів тилового забезпечення військ (сил) в минулих війнах.

До основних таких принципів відносяться:

централізація управління для досягнення ефективного виконання завдань щодо забезпечення потреб Збройних Сил України, 3 урахуванням їх спроможностей, а також ефективного використання наявних ресурсів;

пріоритетність та достатність забезпечення для безперервного i повного задоволення потреб Збройних Сил України у військовому майні та послугах, а також спрямування основних зусиль забезпечення на пріоритетних завданнях, які виконуються силами оборони під час їх застосування;

ефективність використання отриманого військового майна, об'єктів інфраструктури;

гнучкість процесів забезпечення, для підтримання їх функціонування за принципом дії на випереджання зі здатністю до адаптації та швидкого реагування на обставини, що змінюються;

стійкість в організації забезпечення, що повинна передбачати заходи, які спрямовані на мінімізацію втрат виділених ресурсів від впливу певних факторів (зовнішніх i внутрішніх, позитивних i негативних), a у ході ведення операцій (бойових дій) - від впливу противника;

прозорість процесів забезпечення, для забезпечення обміну достовірною інформацією щодо потреб та наявності запасів військового майна, 3 урахуванням забезпечення захисту інформації з обмеженим доступом;

взаємодія та координація дій між складовими силами оборони та центральними (місцевими) органами виконавчої влади, іншими державними органами, органами місцевого самоврядування, підприємствами оборонно-промислового комплексу, іншими підприємствами, установами та організаціями незалежно від форми власності 3 питань забезпечення під час підготовки Збройних Сил України та в ході їх застосування;

відповідальність Збройних Сил України за виконання головної ролі у забезпеченні військовим майном та послугами застосування сил оборони та спільна відповідальність центральних органів виконавчої влади, інших державних органів за забезпечення потреб сил оборони у необхідних силах, засобах та ресурсах;

функціональна сумісність організаційних структур забезпечення Збройних Сил України та можливість інтеграції логістичної системи забезпечення Збройних Сил України або окремих ii елементів під час спільних операцій зі збройними силами країн-членів НАТО.

Якщо під змістом удосконалення управління системою забезпечення розуміти іiі кінцеву мету, то відносно логістики мова повинна йти про набуття Збройними Силами України таких якостей, які забезпечать здатність у мирний час забезпечувати бойову і мобілізаційну готовність військ (сил) у їхньому новому вигляді, а у воєнний час - нарощування їх бойових спроможностей на усіх рівнях ведення збройної боротьби: стратегічному, оперативному і тактичному.

Звідси випливає суть органу управління системою забезпечення військовим майном та послугами військ (сил) у мирний час при запровадженні логістики в Збройних Силах України, що означає необхідність:

переглянути функції як складових елементів системи забезпечення військовим майном, так i всієї системи в цілому;

виявити, що є необхідним і достатнім, а що обтяжливим, надлишковим або дублюючим;

перейти на нові організаційно-штатні структури, вибудувати вертикаль керування ними, систему комплектування i підготовки фахівців служб, що входять в систему;

виробити сучасні підходи до нагромадження, змісту і використанню запасів військового майна, організації військових перевезень і евакуації, технічному оснащенню, військових частин i підрозділів, установ та лікувальних закладів;

удосконалити власну економічну діяльність, поліпшити якість планування, більш ефективно експлуатувати інфраструктуру, оптимізувати витрати на закупівлю і надання послуг, тощо.

Таким чином, кінцева мета - це створення ефективної логістичної системи забезпечення військовим майном та послугами Збройних Сил України, яка спроможна здійснювати планування та управління процесами забезпечення військ (сил) як у мирний час, так і в особливий період та буде сумісною із системою НАТО.

Для виконання цієї мети необхідно виконання таких основних завдань:

створення та нормативно-правове врегулювання функціонування логістики як органу управління системами забезпечення; 
розроблення концепцію розвитку логістики та iii функціонування, якою передбачити виконання заходів, що знаходяться в системі державного управління з залученням галузевих міністерств та відомств, покладення на них відповідальності за забезпечення 3С (сил оборони);

уточнення повноважень, функцій, правових відносин та відповідальності органів виконавчої влади, МО України та ГШ щодо логістики 3С, визначення функцій, завдань i повноважень органів логістики усіх рівнів військового керівництва;

упорядкування функцій i завдань за видами забезпечення i класами постачання між структурними підрозділами сил оборони;

запровадження механізму законодавчого врегулювання відносин суб'єктів господарювання i держави та впровадження нових механізмів забезпечення та надання окремих послуг;

приведення органів (структур) логістики, сил i засобів забезпечення майном та послугами до спроможності ними виконувати завдання 3 забезпечення сил оборони за визначеними завданнями;

чітке визначення ролі та відповідальності кабінету міністрів та інших суб'єктів оборонного планування стосовно вирішення питань логістики

обороноздатності держави;

створення сил і засобів видів забезпечення майном та послугами із необхідним комплектом частин (підрозділів), установ відповідальних за безпосередню реалізацію завдань забезпечення військ (сил) військовим майном;

створення сучасної системи логістики сил оборони України 3 єдиною автоматизованою системою забезпечення військ (сил) військовим майном.

Виходячи 3 вищевикладеного основними напрямками трансформації існуючої системи забезпечення військовим майном та послугами Збройних Сил України є наступні заходи:

повна зміна усіх правил та процедур закупівель, впровадження електронних закупівель та електронного документообігу. Створення нової структури 3 питань закупівель, приєднання до послуг та проектів Агенції НАТО з підтримки та постачання;

підвищення рівня якості військового майна, підвищення рівня відповідальності постачальників (виробників) за якість продукції, а також підвищення рівня довіри до постачальників (виробників) та створення впевненості у зовнішніх та внутрішніх замовників і користувачів в тому, що контрактні вимоги щодо якості були або будуть виконані належним чином;

створення системи державного гарантування якості оборонної продукції;

удосконалення системи надання послуг (аутсорсингу) за прикладом країн-членів НАТО, де послуги 3 харчування надаються структурним підрозділом Міністерства оборони, який зобов“язаний надавати ці послуги як в мирний час, так і в інших випадках;

завершити розподіл функцій забезпечення військ (сил) військовим майном між Міністерством оборони та Генеральним штабом Збройних Сил України;

привести склад і можливості органів логістики, військових частин (підрозділів) і установ (закладів) у відповідність до покладених завдань 3 урахуванням виходу на встановлену чисельність;

удосконалити методи роботи та використання автоматизованих технічних засобів, високих технологій, які полегшують та прискорюють роботу фахівців, що призведе до удосконалення структури та скорочення чисельності органів військового управління, сил та засобів забезпечення;

запровадити принципи відповідності і взаємної сумісності, структурних підрозділів управління та сил забезпечення мирного та воєнного часу, що дозволить виконувати завдання як мирного часу, так і в умовах особливого періоду.

Для цього необхідно реалізувати заходи, які пов'язані 3 оптимізацією системи забезпечення Збройних Сил України, з одночасним доданням максимального ступеня автономності на усіх рівнях:

визначення обсягів і порядку ешелонування запасів військового майна 3 урахуванням скорочення бойового i чисельного складу Збройних Сил України, а також їх перехід до трирівневої структури;

скорочення надлишкової інфраструктури, що безпосередньо не впливає на рівень бойової готовності військ (сил);

удосконалення організаційно-економічних форм господарювання, у тому числі шляхом розширення участі цивільного сектору національної економіки в забезпеченні військ (сил);

модернізація технічної оснащеності видів забезпечення та класів постачання;

оптимізація системи підготовки військовослужбовців і цивільного персоналу за специфікою логістики.

\section{Висновки й перспективи подальших} досліджень

Таким чином, ефективне управління системою забезпечення військовим майном військ (сил) Збройних Сил України підвищить своєчасність та ефективність системи забезпечення, зменшить витрати та оптимізуе процес управління матеріальними, інформаційними і людськими потоками.

Перспективи подальших досліджень вбачаються в формуванні ефективної логістичної системи сил оборони України. 


\begin{abstract}
Jimepamypa
1. Про затвердження Порядку логістичного забезпечення сил оборони під час виконання завдань 3 оборони держави, захисту іiі суверенітету, територіальної цілісності та недоторканності: Постанова Кабінету Міністрів України від 27.12.2018 № 1208.

2. Про затвердження Основних положень логістичного забезпечення 3С України: наказ Міністерства оборони України від 11.10.2016 р. № 522.

3. Доктрина об'єднана логістика: наказ Головнокомандувача ЗС України від 24.09.2020 №2861. $-37 \mathrm{c}$.

4. Доктрина 3 організації переміщень та перевезень (транспортувань) у Збройних Силах України: наказ Генерального штабу Збройних Сил України від 20.08.2020 року № 2464 .

5. Доктрина забезпечення матеріально-технічними засобами, роботами та послугами: наказ Генерального штабу Збройних Сил України від 21.01.2021 року № 225.

6. Доктрина Сил логістики: затверджена Головнокомандувачем ЗС України 08.02.2021 p.

7. Доктрина Застосування сил логістики: затверджена начальником ГШ ЗС України 04.02.2021 року.
\end{abstract}

8. Про правовий режим воєнного стану: Закон України від 12.15.2015 р. № 389-VIII.

9. Про затвердження Положення про порядок обліку, зберігання, списання та використання військового майна у Збройних Сил: постанова Кабінету Міністрів України від 04.082000 р. №1225.

10. Кивлюк В. С., Ганненко Ю. О. Удосконалення системи забезпечення матеріальними ресурсами Збройних Сил України [Електронний ресурс] /В. С.Кивлюк, Ю. О. Ганненко // Social development \& Security. - 2018. - Вип. 2(4). - С. 49-58.

11. Дачковський В. О. Алгоритм функціонування системи логістичного забезпечення / В.О. Дачковський, О.М. Сампір // науковий журнал "Сучасні інформаційні технології у сфері безпеки та оборони”, НУОУ. - 2019. № 2(35) С. 87 - 92 .

12. Основи логістики : навч. посіб. НУОУ ім. Івана Черняховського / В. О. Дачковський, І.В.Овчаренко, О. М. Воробйов, О. В. Ярошенко, Б. О. Мельник, - К. 2018. -204 c.

13. Кальченко А. Г. Логістика: Підручник. - К.: КНЕУ, 2003. $-284 \mathrm{c}$.

\title{
ПРОБЛЕМЫ УПРАВЛЕНИЯ СИСТЕМОЙ ОБЕСПЕЧЕНИЯ ВОЕННЫМ ИМУЩЕСТВОМ ВОЙСК (СИЛ) УКРАИНЫ И ПУТИ ИХ РЕШЕНИЯ
}

\author{
Владимир Семенович Кивлюк (кандидт экономических наук, доцент) \\ Виктор Иванович Лазоренко (кандидат военных наук, доцент) \\ Юрий Александрович Ганненко \\ Михаил Петрович Лаврук
}

\section{Национальный университет обороны Украины имени Ивана Черняховского, Киев, Украина}

В статье на основе проведенного анализа обеспечения войск (сил) Вооруженных Сил Украины на современном этапе развития определенны основные проблемы логистики как органа управления системой обеспечения военным имуществом войск (сил) Украины и предлагаются пути их решения.

Рассматриваются вопросы использования единых терминов и понятий по обеспечению сил обороны в мирное время и особый период. Авторы определяют одну из главных проблем - это создание эффективной логистической системы сил обороны Украины, которая способна осуществлять планирование и управление прочессами обеспечения войск (сил) военным имуществом, как в мирное время, так и в особый период и будет совместима с системой НАТО.

Единственное эффективное функционирование системы обеспечения военным имуществом войск (сил) Вооруженных Сил Украины составляет актуальное задание для органов военного управления, которые организуют обеспечения Вооруженных Сил Украины.

Создание системы обеспечения военным имуществом войск (сил) Вооруженных Сил Украины, как системы управления материальными потоками выдвигает задачу про объединение в единственную систему действующих видов тылового та технического обеспечения, приближаючи их к стандартам HATO.

Система обеспечения рассматривается, как методология разработки ращиональных методов управления обеспечения военным имуществом войск (сил) Вооруженных Сил Украины, направленых на оптимизацию, с минимальными затратами трудовых и материальных ресурсов.

В коние статьи сформулированы направления дальнейших исследований по совершенствованию системой обеспечения сил оборонь государства.

Ключевые слова: военное имущество, информаџионная система, логистика, логистическая система, материальные средства.

PROBLEMS OF MANAGEMENT OF THE SYSTEM OF PROVISION OF MILITARY PROPERTY OF THE TROOPS OF THE ARMED FORCES OF UKRAINE AND WAYS OF THEIR SOLUTION

Volodymyr Kyvlyuk (Candidate of Economic Sciences, Associate Professor)

Viktor Lazorenko (Candidate of Military Sciences, Associate Professor)

Yuriy Hannenko

Mykhaylo Lavruk 


\section{The National Defence University of Ukraine named after Ivan Cherniakhovskyi, Kyiv, Ukraine}

The article, based on the analysis of the troops (forces) of the Armed Forces of Ukraine at the present stage of development identifies the main problems of logistics as a management body for the military property of the troops (forces) of the Armed Forces of Ukraine and suggests ways to solve them.

The issues of using common terms and concepts to ensure the defense forces in peacetime and special periods are considered. The authors identify one of the main problems - the creation of an effective system of defense forces of Ukraine, which is able to plan and manage the process of providing troops (forces) with military property both in peacetime and in special periods and will be compatible with NATO.

The only effective functioning of the systems of providing military property troops (forces) of the Armed Forces of Ukraine is an urgent task for public administration bodies that organize the provision of the Armed Forces of Ukraine.

Establishment of military property support systems (forces) of the Armed Forces of Ukraine, as a material flow management system, solves the problem of unification of existing types of logistics and technical support, placing them in NATO standards.

The support system is considered as a methodology for developing rational methods of managing the provision of military property of the troops (forces) of the Armed Forces of Ukraine, aimed at optimization, with minimal labor and material resources.

Finally, the directions of further research on improving the system of support of the Defense Forces of Ukraine are formulated.

Key words: military property, information system, logistics, logistics system, material means.

\section{References}

1. Pro zatverdzhennya Poryadku lohistychnoho zabezpechennya syl oborony pid chas vykonannya zavdan' $\mathrm{z}$ oborony derzhavy, zakhystu yiyi suverenitetu, terytorial'noyi tsilisnosti ta nedotorkannosti: Postanova Kabinetu Ministriv Ukrayiny vid 27.12.2018 № 1208 .

2. Pro zatverdzhennya Osnovnykh polozhen' lohistychnoho zabezpechennya ZS Ukrayiny: nakaz Ministerstva oborony Ukrayiny vid 11.10.2016 r. № 522 .

3. Doktryna ob'yednana lohistyka: nakaz Holovnokomanduvacha ZS Ukrayiny vid 24.09.2020 №2861. $-37 \mathrm{~s}$.

4. Doktryna $\mathrm{z}$ orhanizatsiyi peremishchen' ta perevezen' (transportuvan') u Zbroynykh Sylakh Ukrayiny: nakaz Heneral'noho shtabu Zbroynykh Syl Ukrayiny vid 20.08.2020 roku № 2464.

5. Doktryna zabezpechennya material'no-tekhnichnymy zasobamy, robotamy ta posluhamy: nakaz Heneral'noho shtabu Zbroynykh Syl Ukrayiny vid 21.01.2021 roku № 225.

6. Doktryna Syl lohistyky: zatverdzhena Holovnokomanduvachem ZS Ukrayiny 08.02.2021 r.

7. Doktryna Zastosuvannya syl lohistyky: zatverdzhena nachal'nykom HSH ZS Ukrayiny 04.02.2021 roku.
8. Pro pravovyy rezhym voyennoho stanu: Zakon Ukrayiny vid 12.15.2015 r. № 389-VIII.

9. Pro zatverdzhennya Polozhennya pro poryadok obliku, zberihannya, spysannya ta vykorystannya viys'kovoho mayna u Zbroynykh Syl: postanova Kabinetu Ministriv Ukrayiny vid 04.082000 r. №1225.

10. Kyvlyuk V. S., Hannenko YU. O. Udoskonalennya systemy zabezpechennya material'nymy resursamy Zbroynykh Syl Ukrayiny [Elektronnyy resurs] /V. S.Kyvlyuk, YU. O. Hannenko // Social development \& Security. - 2018. - Vyp. 2(4). - S. 49-58.

11. Dachkovs'kyy V. O. Alhorytm funktsionuvannya systemy lohistychnoho zabezpechennya / V.O. Dachkovs'kyy, O.M. Sampir // naukovyy zhurnal "Suchasni informatsiyni tekhnolohiyi u sferi bezpeky ta oborony", NUOU. - 2019. - № 2(35) S. 87 - 92.

12. Osnovy lohistyky : navch. posib. NUOU im. Ivana Chernyakhovs'koho / V. O. Dachkovs'kyy, I. V. Ovcharenko, O. M. Vorobyov, O. V. Yaroshenko, B. O. Mel'nyk, - K. 2018. - 204 s.

13. Kal'chenko A. H. Lohistyka: Pidruchnyk. - K.: KNEU, 2003. -284 s.. 